NASA/TM-2003-212463
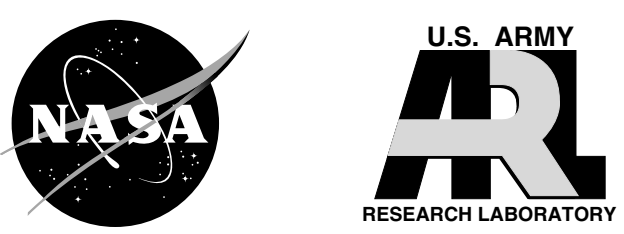

\title{
Increased Surface Fatigue Lives of Spur Gears by Application of a Coating
}

Timothy L. Krantz

U.S. Army Research Laboratory, Glenn Research Center, Cleveland, Ohio

Clark V. Cooper

United Technologies Research Center, East Hartford, Connecticut

Dennis P. Townsend

Townsend Engineering, Westlake, Ohio

Bruce D. Hansen

Sikorsky Aircraft, Stratford, Connecticut 
Since its founding, NASA has been dedicated to the advancement of aeronautics and space science. The NASA Scientific and Technical Information (STI) Program Office plays a key part in helping NASA maintain this important role.

The NASA STI Program Office is operated by Langley Research Center, the Lead Center for NASA's scientific and technical information. The NASA STI Program Office provides access to the NASA STI Database, the largest collection of aeronautical and space science STI in the world. The Program Office is also NASA's institutional mechanism for disseminating the results of its research and development activities. These results are published by NASA in the NASA STI Report Series, which includes the following report types:

- $\quad$ TECHNICAL PUBLICATION. Reports of completed research or a major significant phase of research that present the results of NASA programs and include extensive data or theoretical analysis. Includes compilations of significant scientific and technical data and information deemed to be of continuing reference value. NASA's counterpart of peerreviewed formal professional papers but has less stringent limitations on manuscript length and extent of graphic presentations.

- TECHNICAL MEMORANDUM. Scientific and technical findings that are preliminary or of specialized interest, e.g., quick release reports, working papers, and bibliographies that contain minimal annotation. Does not contain extensive analysis.

- CONTRACTOR REPORT. Scientific and technical findings by NASA-sponsored contractors and grantees.
- CONFERENCE PUBLICATION. Collected papers from scientific and technical conferences, symposia, seminars, or other meetings sponsored or cosponsored by NASA.

- SPECIAL PUBLICATION. Scientific, technical, or historical information from NASA programs, projects, and missions, often concerned with subjects having substantial public interest.

- TECHNICAL TRANSLATION. Englishlanguage translations of foreign scientific and technical material pertinent to NASA's mission.

Specialized services that complement the STI Program Office's diverse offerings include creating custom thesauri, building customized databases, organizing and publishing research results ... even providing videos.

For more information about the NASA STI Program Office, see the following:

- Access the NASA STI Program Home Page at http://www.sti.nasa.gov

- E-mail your question via the Internet to help@sti.nasa.gov

- Fax your question to the NASA Access Help Desk at 301-621-0134

- Telephone the NASA Access Help Desk at 301-621-0390

- Write to:

NASA Access Help Desk

NASA Center for AeroSpace Information 7121 Standard Drive

Hanover, MD 21076 
NASA/TM-2003-212463

ARL-TR-2971
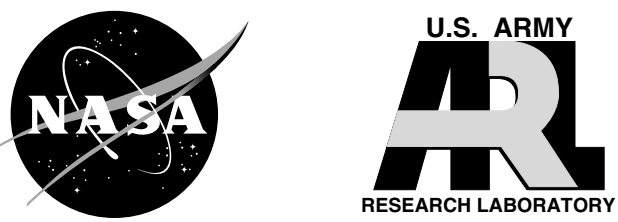

\section{Increased Surface Fatigue Lives of Spur Gears by Application of a Coating}

Timothy L. Krantz

U.S. Army Research Laboratory, Glenn Research Center, Cleveland, Ohio

Clark V. Cooper

United Technologies Research Center, East Hartford, Connecticut

Dennis P. Townsend

Townsend Engineering, Westlake, Ohio

Bruce D. Hansen

Sikorsky Aircraft, Stratford, Connecticut

Prepared for the

2003 International Design Engineering Technical Conferences and Computers and Information in Engineering Conference

sponsored by the American Society of Mechanical Engineers

Chicago, Illinois, September 2-6, 2003

National Aeronautics and

Space Administration

Glenn Research Center 
The Propulsion and Power Program at NASA Glenn Research Center sponsored this work.

Available from

NASA Center for Aerospace Information 7121 Standard Drive

Hanover, MD 21076
National Technical Information Service 5285 Port Royal Road Springfield, VA 22100

Available electronically at http:/ /gltrs.grc.nasa.gov 


\section{DETC2003-48114}

\section{INCREASED SURFACE FATIGUE LIVES OF SPUR GEARS BY APPLICATION OF A COATING}

\author{
Timothy L. Krantz \\ Army Research Laboratory \\ Cleveland, Ohio USA \\ Dennis P. Townsend \\ Townsend Engineering \\ Westlake, Ohio USA
}

Timothy.L.Krantz@grc.nasa.gov 216-433-3580

\author{
Clark V. Cooper \\ United Technologies Research Center \\ East Hartford, Connecticut USA \\ Bruce D. Hansen \\ Sikorsky Aircraft \\ Stratford, Connecticut USA
}

\begin{abstract}
Hard coatings have potential for increasing gear surface fatigue lives. Experiments were conducted using gears both with and without a metal-containing, carbonbased coating. The gears were case-carburized AISI 9310 steel spur gears. Some gears were provided with the coating by magnetron sputtering. Lives were evaluated by accelerated life tests. For uncoated gears, all of fifteen tests resulted in fatigue failure before completing 275 million revolutions. For coated gears, eleven of the fourteen tests were suspended with no fatigue failure after 275 million revolutions. The improved life owing to the coating, approximately a six-fold increase, was a statistically significant result.
\end{abstract}

Keywords: Gear, life, fatigue, pitting, coatings.

\section{INTRODUCTION}

The power density of a gearbox is an important consideration for many applications and is especially important for gearboxes used on aircraft. One factor that limits gearbox power density is the need to transmit power for the required number of cycles while avoiding gear surface fatigue failure (micropitting, pitting or spalling). Effective and economical methods for improving surface fatigue lives of gears are therefore highly desirable. Thin hard coatings have potential for improving gear performance. In fact, coatings are reported to have some successful applications [1-3] where product durability improvements have been achieved by the application of thin hard coatings to gears.

Diamond-like carbon and related materials have the potential for a wide variety of applications that require wear protection and/or low-friction properties. Because of the widely recognized potential, the deposition methods and resulting properties of the films have been studied extensively [4-6]. Today's deposition technology allows for the production of a great diversity of coatings, but the ability to tailor the tribological behavior of a coating for a particular application has been elusive.

Aerospace gearing requirements are demanding, calling for high power density, long life, and excellent reliability. The low friction properties and high hardness of diamond-like and related coatings offer the possibility to improve the performance of aerospace gearing. Naik, et al [7] tested the adherence and toughness of two coatings using both disk-on-rod rolling-contact and gear tests, and they reported promising results. Alanou, et al [8] found that coatings could increase the scuffing load capacity of rolling and sliding disks used to simulate aerospace gearing contacts, but they also reported poor adherence for one particular substrate and coating combination. Joachim, Kurz and Glatthaar [3] reported promising results of evaluations of tungsten carbon carbide and amorphous boron carbide coatings using laboratory tests, but they also report mixed results when applying such coatings to commercial applications.

The purpose of the present investigation was to compare the surface fatigue lives of coated and uncoated gears using accelerated life tests. The testing is considered as accelerated in that the contact stresses used for testing exceeds the stresses used for design of the target application (helicopter gearing). The metalcontaining, carbon-based diamond-like (Me-DLC) coating selected for this study was designed specifically for the aerospace gearing applications. 


\section{DESCRIPTION OF THE TEST GEARS, LUBRICANT, AND COATING}

The test gears used for this work were manufactured in one lot from a single heat of consumable-electrode vacuum-melted (CVM) AISI 9310 steel. The nominal chemical composition of the AISI 9310 material is given in Table 1. The gears were case carburized and heat treated according to Table 2 . Figure 1 is a photomicrograph of an etched and polished gear tooth showing the case and core microstructure of the test gears. The nominal properties of the carburized gears were a case hardness of Rockwell C60, a case depth of $0.97 \mathrm{~mm}$ (0.038 in.), and a core hardness of Rockwell C38. The test gears were a subset of a larger lot of gears that were used by Townsend and Shimski [9] to study the influence of elastohydrodynamic film thickness and extreme pressure additives on gear surface fatigue life.

TABLE 1.-_Nominal Chemical Composition of AISI 9310 Gear Material

\begin{tabular}{|l|c|}
\hline Element & Weight \% \\
\hline Carbon & 0.10 \\
\hline Nickel & 3.22 \\
\hline Chromium & 1.21 \\
\hline Molybdenum & 0.12 \\
\hline Copper & 0.13 \\
\hline Manganese & 0.63 \\
\hline Silicon & 0.27 \\
\hline Sulfur & 0.005 \\
\hline Phosphorous & 0.005 \\
\hline Iron & balance \\
\hline
\end{tabular}

TABLE 2 - Heat treatment for AISI 9310 Gears.

\begin{tabular}{|c|c|c|c|c|}
\hline \multirow[t]{2}{*}{ Step } & \multirow[t]{2}{*}{ Process } & \multicolumn{2}{|c|}{ Temperature } & \multirow[t]{2}{*}{ Time, $\mathrm{hr}$} \\
\hline & & $\bar{K}$ & ${ }^{\circ} \mathrm{F}$ & \\
\hline 1 & Preheat in air & - & - & - \\
\hline 2 & Carburize & 1,172 & 1,650 & 8 \\
\hline 3 & $\begin{array}{l}\text { Air cool to room } \\
\text { temperature }\end{array}$ & - & - & - \\
\hline 4 & $\begin{array}{l}\text { Copper plate all } \\
\text { over }\end{array}$ & - & - & - \\
\hline 5 & Reheat & 922 & 1,200 & 2.5 \\
\hline 6 & $\begin{array}{l}\text { Air cool to room } \\
\text { temperature }\end{array}$ & - & - & - \\
\hline 7 & Austentize & 1,117 & 1,550 & 2.5 \\
\hline 8 & Oil quench & - & - & - \\
\hline 9 & Subzero cool & 180 & -120 & 3.5 \\
\hline 10 & Double temper & 450 & 350 & 2 each \\
\hline 11 & Finish grind & - & - & - \\
\hline 12 & Stress relieve & 450 & 350 & 2 \\
\hline
\end{tabular}

The dimensions for the test gears are given in Table 3. The gear pitch diameter was $89 \mathrm{~mm}$ (3.5 in.,) and the tooth form was a $20^{\circ}$ involute profile modified to provide a tip relief of $0.013 \mathrm{~mm}(0.0005 \mathrm{in}$.) starting at the highest point of single tooth contact. The gear tooth surface finish after final grinding was specified as a maximum of $0.406 \mu \mathrm{m}$ (16 $\mu \mathrm{in}$.) root-mean-squared (r.m.s.).

TABLE 3 -Spur Gear Data.

[Gear Tolerance Per AGMA Class 12].

\begin{tabular}{|lr|}
\hline Number of teeth & 28 \\
\hline Module, mm & 3.175 \\
\hline Diametral pitch & 8 \\
\hline Circular pitch, mm (in.) & $9.975(0.3927)$ \\
\hline Whole depth, mm (in.) & $7.62(0.300)$ \\
\hline Addendum, mm (in.) & $3.18(.125)$ \\
\hline $\begin{array}{l}\text { Chordal tooth thickness } \\
\text { reference, mm (in.) }\end{array}$ & $4.85(0.191)$ \\
\hline Tooth width, mm (in.) & $6.35(0.25)$ \\
\hline Pressure angle, deg. & 20 \\
\hline Pitch diameter, mm (in.) & $88.90(3.500)$ \\
\hline Outside diameter, mm (in.) & $95.25(3.750)$ \\
\hline Root fillet, mm (in.) & 1.02 to 1.52 \\
\hline $\begin{array}{l}\text { Measurement over pins, } \\
\text { mm (in.) }\end{array}$ & 9.04 to 0.06) \\
\hline Pin diameter, mm (in.) & 96.03 to 96.30 \\
\hline $\begin{array}{l}\text { Backlash reference, mm } \\
\text { (in.) }\end{array}$ & 5.7807 to 3.7915) \\
\hline Tip relief, mm (in.) & 0.254 (0.010) \\
\hline
\end{tabular}

The lubricant used for testing was from a single batch of synthetic paraffinic oil. Physical properties of this lubricant are summarized in Table 4. Five percent of extreme pressure additive with partial contents including phosphorus and sulfur was added to the lubricant. This lubricant and additive combination has been used extensively for gear fatigue testing in the NASA Glenn spur gear fatigue rigs. For example, Krantz [10] reported 146 tests using this same oil (termed "NASA standard" in the referenced article) to evaluate the surface fatigue lives of AISI 9310 steel gears. The oil and additive mixture used in this work is similar to 5centistoke oils used for helicopter main gearboxes. The film thickness at the pitch point for the operating conditions of the surface fatigue testing was calculated using the computer program EXTERN. This program, developed at the NASA Glenn Research Center, is based on the methods of Anderson, Lowenthal, and Black [11,12]. For the purposes of the calculation, the gear surface temperature was assumed to be equal to the average oil outlet temperature. This gave a calculated pitch-line film thickness of $0.54 \mu \mathrm{m}(21 \mu \mathrm{in}$.). 

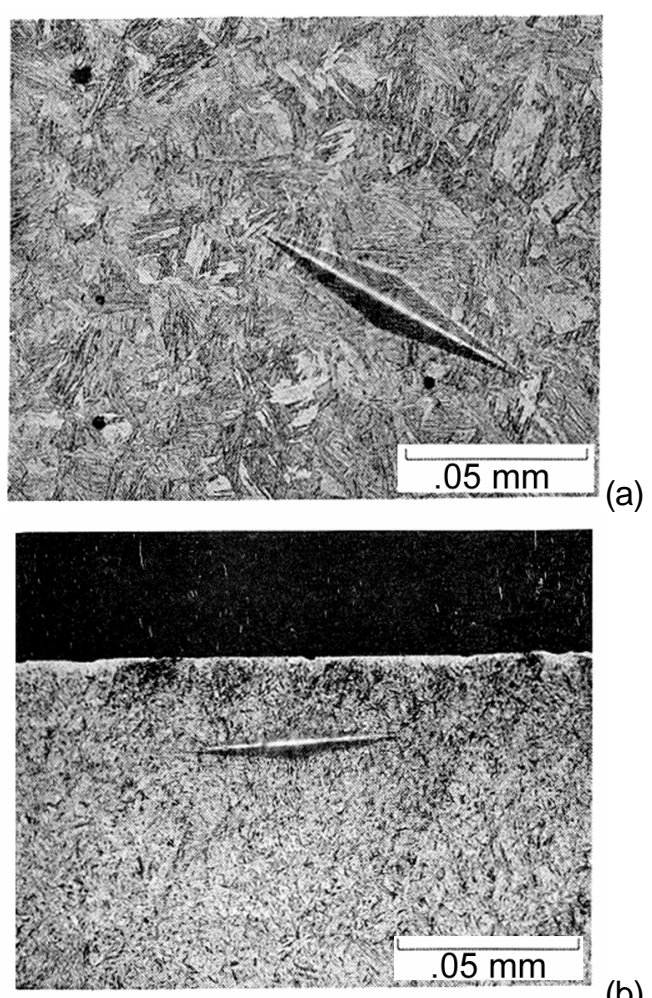

(b)

Figure 1.-Photomicrograph of an etched and polished test gear tooth (from Townsend and Shimski, ref. [9]). (a) Core microstructure. (b) Case microstructure.

TABLE 4. - Lubricant Properties.

\begin{tabular}{|lr|}
\hline Additive & ${ }^{\mathrm{a}}$ Lubrizol 5002 \\
Kinematic viscosity, cSt & 31.6 \\
$311 \mathrm{~K}\left(100^{\circ} \mathrm{F}\right)$ & 5.7 \\
$372 \mathrm{~K}\left(210^{\circ} \mathrm{F}\right)$ & 0.83 \\
Specific gravity & $544(520)$ \\
Flash point, $\mathrm{K}\left({ }^{\circ} \mathrm{F}\right)$ & $211(-80)$ \\
\hline Pour point, $\mathrm{K}\left({ }^{\circ} \mathrm{F}\right)$ & $\left.{ }^{2}\right)$ \\
\hline
\end{tabular}

W(tungsten)-DLC coatings were deposited onto carburized spur gears after final grinding, by using an unbalanced magnetron sputter deposition process, at a deposition temperature of approximately $200^{\circ} \mathrm{C}$ [13]. Prior to coating deposition, the spur gears were "vapor honed" using pressurized water-based media containing $\sim 10 \mu \mathrm{m}$ diameter $\mathrm{Al}_{2} \mathrm{O}_{3}$ particles. The coating/gear system consisted of an elemental $\mathrm{Cr}$ (chromium) adhesion layer adjacent to the steel substrate, followed by an intermediate, transition region, featuring alternating lamellae composed of $\mathrm{Cr}$ and WC, and an outermost Wcontaining hydrocarbon (W-C:H) layer. The composition of the outermost $\mathrm{W}-\mathrm{C}: \mathrm{H}$ layer, in atomic percent, has been determined via secondary ion mass spectrometry (SIMS) to be approximately $12 \% \mathrm{~W}, 70 \% \mathrm{C}, 15 \% \mathrm{H}$, and $3 \% \mathrm{Ni}$, which forms the binder element for the WC sputter targets [14].

Measurements of the properties of Me-DLC coating materials are sparse, primarily on W-DLC coatings [15-18]. The Young's modulus of the DLC coating is in the range $100-120 \mathrm{GPa}$ as measured using beamcurvature $[15,16]$ and instrumented indentation $[17,18]$ methods. W-DLC deposited on steel is in residual compression. Measurements performed by beam curvature indicate a stress, $\sigma_{R} \approx-900 \mathrm{MPa}[15]$; the amorphous nature of the Me-DLC coating $[19,20]$ precludes stress measurement through the application of $x$-ray diffraction methods. The fracture toughness of the W-DLC has been determined from the critical strain for channel cracking [15] as: $\Gamma_{D L C} \approx 35 \mathrm{Jm}^{-2}$. The toughness of the interface between the W-DLC coating and the steel substrate in the presence of a $\mathrm{Cr}$ adhesion layer has been shown to be well in excess of that for the Me-DLC coating, itself [15]. This high toughness eliminates the interface as a weak link and distinguishes the present systems from those with weak interfaces.

\section{TEST APPARATUS AND PROCEDURE}

The gear fatigue tests were performed in the NASA Glenn Research Center's gear test apparatus. The test rig is shown in Fig. 2(a) and described in reference [21]. The rig uses the four-square principle of applying test loads, and thus the input drive only needs to overcome the frictional losses in the system. The test rig is belt driven and operated at a fixed speed of 10000 r.p.m. for the duration of a particular test.

A schematic of the apparatus is shown in Fig. 2(b). Oil pressure and leakage replacement flow is supplied to the load vanes through a shaft seal. As the oil pressure is increased on the load vanes located inside one of the slave gears, torque is applied to its shaft. This torque is transmitted through the test gears and back to the slave gears. In this way power is circulated, and the desired load and corresponding stress level on the test gear teeth may be obtained by adjusting the hydraulic pressure. The two identical test gears may be started under no load, and the load can then be applied gradually. This arrangement also has the advantage that changes in load do not affect the width or position of the running track on the gear teeth. To enable testing at the desired contact stress, the gears are tested with the faces offset as shown in Fig. 2. By utilizing the offset arrangement for both faces of the gear teeth, a total of four surface fatigue tests can be run for each pair of gears.

Separate lubrication systems are provided for the test and slave gears. The two lubrication systems are separated at the gearbox shafts by pressurized labyrinth seals, with nitrogen as the seal gas. The test gear lubricant is filtered through a $5-\mu \mathrm{m}(200-\mu \mathrm{in}$.) nominal fiberglass filter.

A vibration transducer mounted on the gearbox is used to automatically stop the test rig when the broadband r.m.s. vibration magnitude increases beyond a threshold, indicating that gear surface fatigue damage has occurred. The gearbox is also automatically stopped if there is a loss of oil flow to either the slave gearbox or the test gears, if the test gear oil overheats, or if there is a loss of seal gas pressurization.

The test gears were run with the tooth faces offset by a nominal $3.3 \mathrm{~mm}(0.130 \mathrm{in}$.) to give a surface load width 
on the gear face of $3.0 \mathrm{~mm}(0.120 \mathrm{in})$. The actual tooth face offset for each test is based on the measured face width of the test specimen, and the offset is verified upon installation using a depth gage. The nominal $0.13-\mathrm{mm}$ (0.005-in.-) radius edge break is accounted for to calculate load intensity. All tests were run-in at a load (normal to the pitch circle) per unit width of $123 \mathrm{~N} / \mathrm{mm}$ (700 lb/in.) for 1 hour. The load was then increased to the desired test load. For the uncoated gears, all tests were conducted using a test load of $580 \mathrm{~N} / \mathrm{mm}$ (3300 lb/in.), which resulted in a 1.7-GPa (250-ksi) pitch-line maximum Hertz stress. For the coated gears, six tests were conducted at the same test load as was used for the uncoated gears while eight tests were conducted using a test load of $720 \mathrm{~N} / \mathrm{mm}(4100 \mathrm{lb} / \mathrm{in}$.) which resulted in a 1.9-GPa (280-ksi) pitch-line maximum Hertz stress. The Hertz stress just stated is an idealized stress index assuming static equilibrium, perfectly smooth surfaces, and an even pressure distribution across a $2.79 \mathrm{~mm}$ ( 0.110 in.) line contact (the line length is less than the face width allowing for the face offset and the radius edge break).

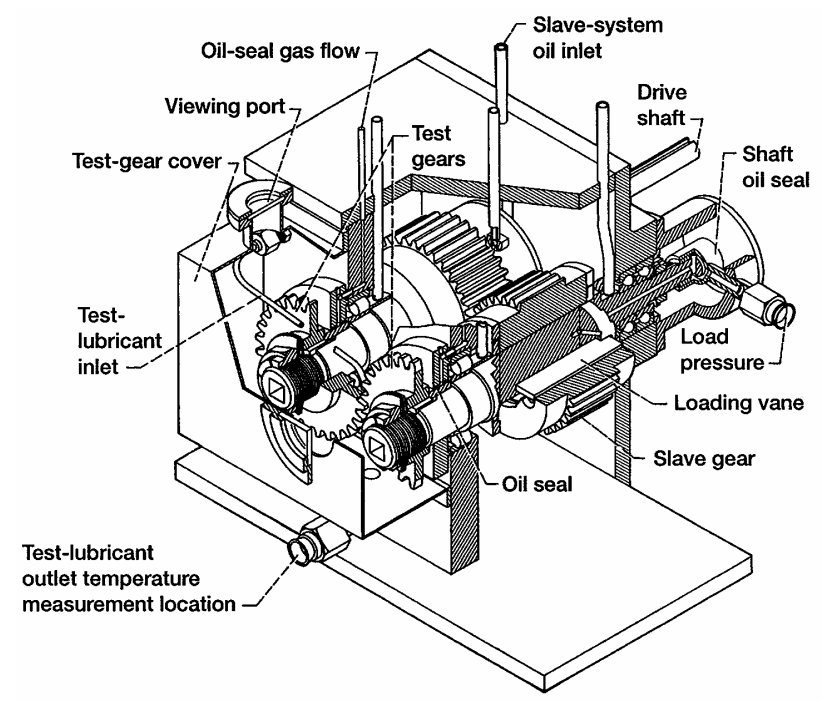

(a)

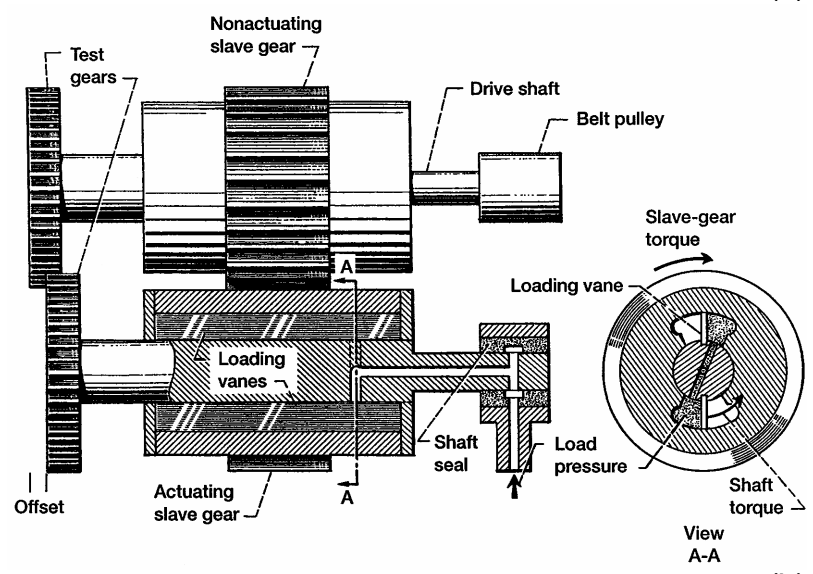

(b)

Figure 2.-NASA Glenn Research Center gear fatigue test apparatus. (a) Cutaway view. (b) Schematic view.
Typical dynamic tooth forces using the same rigs and gears of the same specification have been measured (Krantz, [10]), and the results are provided in Fig. 3. The tooth forces reported in Fig. 3 are the dynamic forces normal to the tooth surface for a nominal pitch-line test load intensity of $580 \mathrm{~N} / \mathrm{mm}$ (3300 lb/in.). The contact force used for stress calculations for such load intensity was $1720 \mathrm{~N}(387 \mathrm{lb})$. This value for the contact force is the value required for static equilibrium, and it is somewhat less than the measured dynamic forces.

The gears were tested at $10000 \mathrm{rpm}$, which gave a pitch-line velocity of $46.5 \mathrm{~m} / \mathrm{s}(9154 \mathrm{ft} / \mathrm{min})$. Inlet and outlet oil temperatures were continuously monitored. Cooled lubricant was supplied to the inlet of the gear mesh at $0.8 \mathrm{liter} / \mathrm{min}(0.2 \mathrm{gal} / \mathrm{min})$ and $320 \pm 7 \mathrm{~K}$ $\left(116 \pm 13^{\circ} \mathrm{F}\right)$. The lubricant outlet temperature was recorded and observed to have been maintained at $348 \pm 4.5 \mathrm{~K}\left(166 \pm 8^{\circ} \mathrm{F}\right)$. The lubricant was circulated through a $5-\mu \mathrm{m}-(200-\mu$ in. -$)$ nominal fiberglass filter to remove wear particles. For each test, 3.8 liter ( $1 \mathrm{gal})$ of lubricant was used. The tests ran continuously (24 hr/day) until a vibration detection transducer automatically stopped the rig. The transducer is located on the gearbox housing. The gears were also inspected visually at intervals of approximately 50 million cycles. For purposes of this work, surface fatigue failure was defined as one or more spalls or pits covering at least 50 percent of the width of the Hertzian line contact on any one tooth. If the gear pairs operated for more than 460 hours (corresponding to 275 million stress cycles) without failure, the test was suspended.

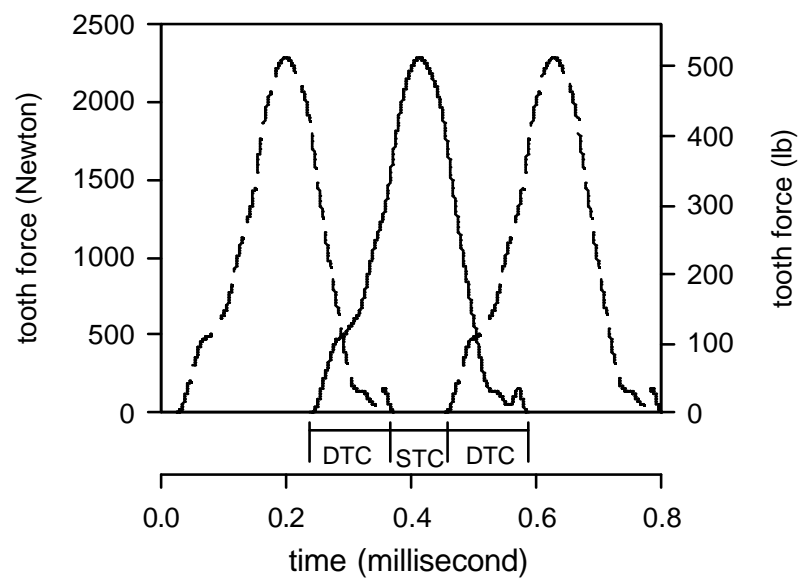

Figure 3.-Measured dynamic tooth force at nominal test conditions (from Krantz, ref. [10]). The solid line is the measured data, and the dashed lines are replicates of the measured data spaced along the ordinate at the equivalent of one tooth pitch. The zones of double tooth contact (DTC) and single tooth contact (STC) are illustrated.

\section{TEST RESULTS AND DISCUSSION}

Results of the gear surface fatigue testing are summarized in Table 5 . A total of 29 tests were completed, 15 tests using the uncoated gears and 14 
tests using the coated gears. All of the baseline tests were conducted at a Hertzian stress index of $1.7 \mathrm{GPa}$ (250 ksi), with all tests resulting in failures. The range of duration for the tests using uncoated baseline gears was 25-272 million revolutions. The coated gears were tested at two loads. Six of the coated gears were tested at a Hertzian stress index of $1.7 \mathrm{GPa}(250 \mathrm{ksi})$, and eight of the coated gears were tested at a stress index of 1.9 $\mathrm{GPa}(280 \mathrm{ksi})$. The range of duration for the tests using coated gears was 63-311 million revolutions, and 11 of the 14 tests were completed with no failure after at least 275 million revolutions.

\section{TABLE 5. - Summary of test results}

\begin{tabular}{|l|c|c|c|c|}
\hline Gear type & $\begin{array}{c}\text { Hertz } \\
\text { stress } \\
\text { index } \\
(\mathrm{GPa})\end{array}$ & $\begin{array}{c}\text { Number } \\
\text { of tests }\end{array}$ & $\begin{array}{c}\text { Number } \\
\text { of } \\
\text { failures }\end{array}$ & $\begin{array}{c}\text { Number without } \\
\text { failure (after } \\
275 \times 10^{6} \\
\text { revolutions) }\end{array}$ \\
\hline uncoated & 1.7 & 15 & 15 & 0 \\
\hline coated & 1.7 & 6 & 1 & 5 \\
\cline { 2 - 5 } & 1.9 & 8 & 2 & 6 \\
\hline
\end{tabular}

The distributions of the fatigue lives were modeled as 2-parmeter Weibull distributions (Weibull, [22] and Hallinan, 23]). The fatigue lives are system lives, the system consisting of two identical gears. Tests that were suspended after pre-specified times showed no signs of impending failure, and so such tests were treated as right-censored life tests for the purpose of statistical analysis. It was decided not to estimate the slope of the coated gear population with only 3 failure data points. Instead, it was assumed that the coated and uncoated gears had life distributions with equal Weibull slope parameters. A likelihood ratio statistical test (Meeker and Escobar, [24]) was used to verify that the assumption of equal slopes was indeed a reasonable assumption. Software employing the maximum likelihood method (Krantz, [25]) was used to estimate the Weibull parameter values from the test data. Figure 4 is a Weibull plot displaying the test data and the lines representing the maximum likelihood fit Weibull distributions. Data points are plotted at the positions of exact median ranks (Jaquelin, [26]) with adjustments to the order numbers to account for suspended tests (Johnson, [27]). The results of the statistical analysis are summarized in Table 6 . The ten-percent lives of the uncoated and coated gear populations were estimated to be $28 \times 10^{6}$ and $180 \times 10^{6}$ cycles, respectively.

From the data plot and the statistical analysis, it is clear that the lives of the coated gears were longer than the lives of the uncoated gears by a factor of approximately six. To test that the measured life difference was a statistically significant one, the null hypothesis was set forth that the coated and uncoated gears represented a single fatigue life population. If the null hypothesis were true, the observed life difference would have come about from random sampling effects. The null hypothesis was tested using the likelihood ratio method (Meeker and Escobar, [24]), and it was found that the null hypothesis can be rejected with greater than 99.5 percent confidence, a statistically significant difference.

TABLE 6. - Summary of Weibull statistical analysis.

\begin{tabular}{|c|c|c|c|c|}
\hline Gear type & $\begin{array}{l}\text { Weibull } \\
\text { slope }\end{array}$ & $\begin{array}{c}\text { Scale } \\
\left(10^{6}\right. \\
\text { cycles })\end{array}$ & $\begin{array}{c}\text { 10-percent } \\
\text { live } \\
\left(10^{6}\right. \\
\text { cycles })\end{array}$ & $\begin{array}{c}50 \text {-percent } \\
\text { life } \\
\left(10^{6}\right. \\
\text { cycles })\end{array}$ \\
\hline uncoated & $1.7^{*}$ & 105 & 28 & 83 \\
\hline coated & $1.7^{\star}$ & 673 & 180 & 530 \\
\hline
\end{tabular}

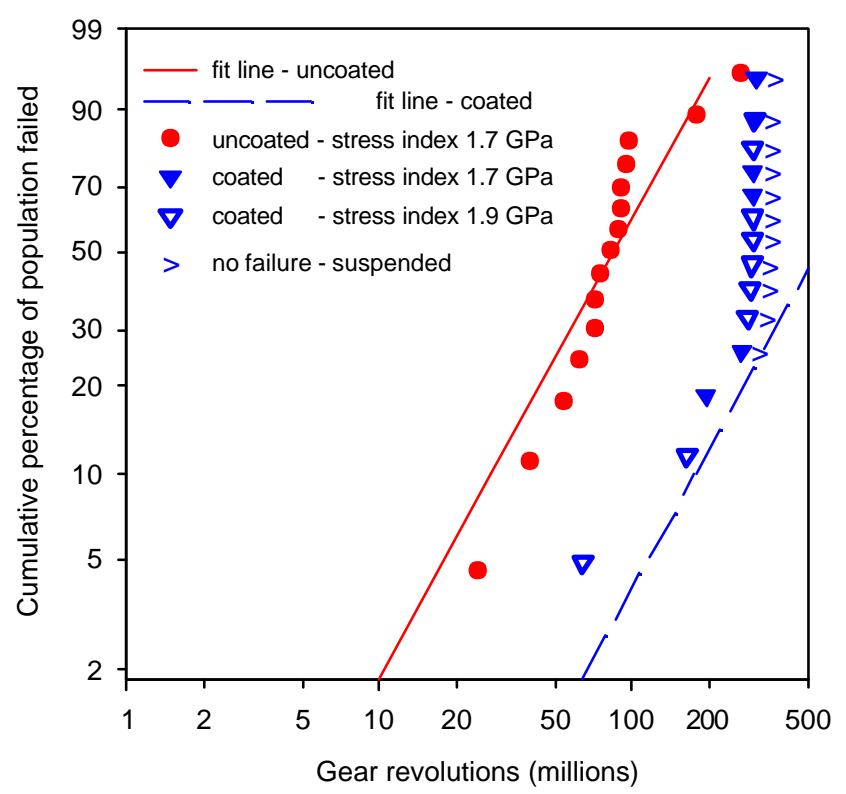

Figure 4.-Weibull plot of the fatigue test results with best fit lines as was estimated using the maximum likelihood method.

The preceding text provides a quantitative assessment of the influence of the coating on gear surface fatigue life. One can also make a qualitative comparison to other gear fatigue studies that have been conducted using the same test rigs, the same test procedure, the same gear material, and the same lubricant. Table 7 provides a compilation of gear fatigue test data gathered from references [28-32]. The table is sorted by the measured 10-percent life, except the gears of the present study occupy the last two rows of the table. The measured fatigue lives of the uncoated-baseline gears of the present study are consistent with the historical database for the AISI 9310 gear steel. The coating used for the present study provided for significantly longer surface fatigue lives of the gear tooth surfaces. The coating performance is especially impressive keeping in mind that for the coated gears, eight of the fourteen tests were conducted at a higher Hertzian stress (1.9 GPa) than was the stress (1.7 GPa) for the other tests reported in Table 7.

Figure 5 provides images of the tested gears showing tested surfaces with fatigue failures. The figure shows 
typical features of the failed surfaces, and regardless if the gear was coated or uncoated the pitted teeth had similar features. For both the uncoated and coated surfaces, the surface topography changes with running. The surfaces take on a smoother appearance, and there is evidence of wear. By subjective evaluation, it appears that the total amount of wear on the coated surfaces is less than that of the uncoated surfaces. Because of the face-offset testing method, there remains in the middle of a tested gear a thin track of tooth surface that was not in contact. Tracing across a tested tooth surface using a soft stylus, one can feel a clear wear step on the uncoated gears. Such a step could not be detected on the coated and tested gears. One could speculate that the longer fatigue lives of the coated gears were a result of the wear protection offered by the coating. Such a mechanism has been stated as an explanation for an increase of fatigue lives for bearings due to providing a coating to rolling elements of bearings (Olofsson, et al, Ref. [33]). It has been speculated in the literature that improved durability of coated surfaces can in some cases be attributed to a polishing mechanism (Polonsky, et al, Refs. $[34,35])$. That is, one can consider that the surfaces polish one another during initial running. Some guidance concerning the abrasive and polishing characteristics of hard coatings can be found in the literature (Refs. [36-39]). Based on data from these studies, it is likely that the running-in and polishing of micro-scale features of the coated surface occurred during a fraction of the total running times of the gears.

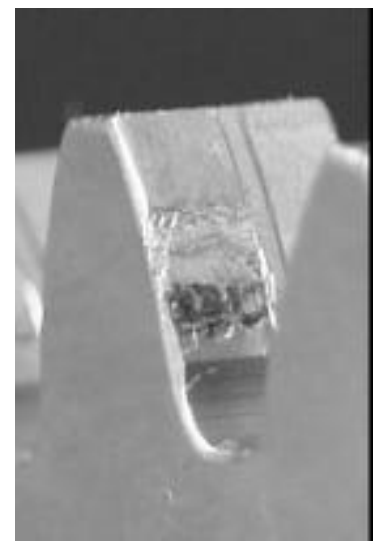

(a)

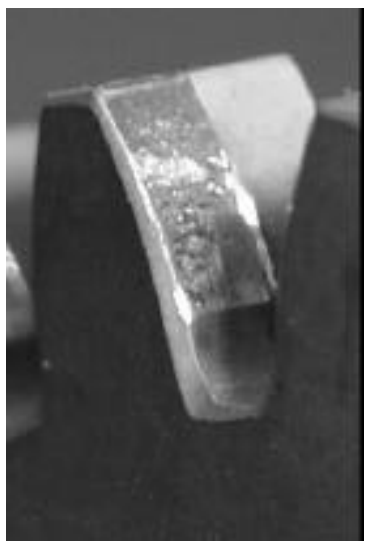

(b)
Figure 5-Typical appearance of failed gear tooth surfaces. (a) Uncoated gear. (b) Coated gear.

The increased surface fatigue lives due to polishing (or superfinishing) of uncoated, high quality, ground gears has been clearly established (Refs. [10, 40, 41]). It has been speculated that the increase of surface fatigue lives for superfinished gears might be due to reductions of asperity interactions (Refs. [10, 42]). It is considered likely that for coated gears, the changes to the topography of the tooth surface during running plays an important role concerning the surface fatigue.

To help characterize the running-in characteristics of the coated and tested gears, a tested gear was inspected using a scanning-electron microscope. Figure 6 shows typical features at three levels of resolution. At low resolution (Fig. 6[a]), one can see traces of the grinding marks, indicating that the coating thickness was uniform enough such that application of the coating did not significantly change the surface topography. Figure 6(a) also shows the contact pattern, with the run-in portion of the surface appearing as slightly darker than the un-run portion of the surface. Figure 6 (b) shows a portion of the surface of Fig. 6(a) at a somewhat higher resolution. It appears that the coating has been smoothed and/or removed (darker areas) along certain grinding-mark features. Figure 6 (c) shows the same portion of the tooth at a still higher resolution. The spherical shape of the coating micro-structure is evident, and a portion of the surface has been smoothed. By using backscatter electron micrographs and energy dispersive $\mathrm{x}$-ray spectrums, it was found that in localized areas the coating had been removed from the surface.

\section{SUMMARY}

The purpose of the present investigation was to compare the surface fatigue lives of coated and uncoated gears using accelerated life tests. The test gears used were manufactured in one lot from a single heat of consumable-electrode vacuum-melted (CVM) AISI 9310 steel. The gears were case-carburized and ground to aerospace quality. A subset of the ground gears was provided with a thin, hard, low-friction coating by magnetron sputtering, a physical vapor deposition (PVD) process. The coating that was applied to the gears was a metal-containing, carbon-based (Me-DLC) coating. Tests were conducted using a four-square type gear fatigue rig. Tests were run until either of surface fatigue failure of any one gear tooth or until a predetermined number of cycles had occurred with no failure. The following specific results were obtained.

1. Fifteen tests were completed using the uncoated gears using a load intensity corresponding to a Hertzian stress index of $1.7 \mathrm{GPa}$ (250 ksi).

2. Fourteen tests were completed using the coated gears. Two load intensities were used for the coated gears, with six tests conducted at a Hertzian stress index of $1.7 \mathrm{GPa}(250 \mathrm{ksi})$ and eight tests conducted at a stress ndex of 1.9 GPa (280 ksi).

3. For the uncoated gears, all tests resulted in failure with test durations ranging from $25-272$ million revolutions.

4. For the coated gears, three of the tests resulted in failure while eleven tests were suspended without failure. The testing durations ranged from 63-311 million revolutions.

5. The distributions of the fatigue lives were modeled as 2-parmeter Weibull distributions. From the Weibull analysis, the ten-percent lives of the uncoated and coated gear populations were estimated to be $28 \times 10^{6}$ and $180 \times 10^{6}$ cycles, respectively.

6. The measured life difference is a statistically significant difference to a greater than 99.5 percent statistical confidence. 
Table 7.--Surface fatigue lives of case-carburized AISI 9310 gear pairs tested in the NASA Glenn Research Center gear fatigue test apparatus. All tests conducted using gears of the same geometry, same heat treat specification, same lubricant, same testing speed of 10000 r.p.m., and same testing methods.

\begin{tabular}{|c|l|l|c|c|c|l|l|}
\hline Reference & $\begin{array}{c}\text { Year } \\
\text { published }\end{array}$ & \multicolumn{1}{|c|}{ Mat erial $^{\mathrm{a}}$} & $\begin{array}{c}10-\text { Percent } \\
\text { life, } \\
\text { cycles }^{\mathrm{b}}\end{array}$ & $\begin{array}{c}50-\text { Percent } \\
\text { life, } \\
\text { cycles }^{\mathrm{b}}\end{array}$ & $\begin{array}{c}\text { Weibull } \\
\text { slope }\end{array}$ & $\begin{array}{l}\text { Failure } \\
\text { index }^{\mathrm{c}}\end{array}$ & \multicolumn{1}{|c|}{ Comments } \\
\hline 28 & 1982 & CVM AISI 9310 & $19 \times 10^{6}$ & $46 \times 10^{6}$ & 2.1 & $18 / 18$ & Ground \\
\hline 29 & 1995 & CVM AISI 9310 & $21 \times 10^{6}$ & $45 \times 10^{6}$ & 2.4 & $19 / 20$ & Ground \\
\hline 30 & 1980 & CVM AISI 9310 & $23 \times 10^{6}$ & $52 \times 10^{6}$ & 2.3 & $30 / 30$ & Ground \\
\hline 28 & 1982 & CVM AISI 9310 & $30 \times 10^{6}$ & $68 \times 10^{6}$ & 2.3 & $24 / 24$ & Ground, shot peened. \\
\hline 31 & 1992 & VIM-VAR AISI 9310 & $42 \times 10^{6}$ & $140 \times 10^{6}$ & 1.6 & $14 / 20$ & Ground, medium-intensity shot peened \\
\hline 32 & 1989 & VIM-VAR AISI 9310 & $48 \times 10^{6}$ & $200 \times 10^{6}$ & 1.3 & $24 / 33$ & Ground \\
\hline 31 & 1992 & VIM-VAR AISI 9310 & $89 \times 10^{6}$ & $250 \times 10^{6}$ & 1.9 & $13 / 20$ & Ground, high-intensity shot peened \\
\hline N/A & $\mathbf{2 0 0 3}$ & CVM AISI 9310 & $28 \times 10^{6}$ & $83 \times 10^{6}$ & 1.7 & $15 / 15$ & Ground (present study, baseline) \\
\hline N/A & $\mathbf{2 0 0 3}$ & CVM AISI 9310 & $180 \times 10^{6}$ & $530 \times 10^{6}$ & 1.7 & $3 / 14$ & Ground and coated (present study) \\
\hline
\end{tabular}

${ }^{\mathrm{a}} \mathrm{CVM}$ indicates consumable-electrode vacuum-melted; VIM-VAR indicates vacuum-induction-melted + vacuum-arc-remelted

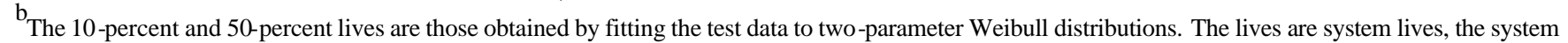
being a pair of gears.

${ }^{c}$ Indicates the number of failures out of the number of tests. The durations of tests suspended without failure were in the range $275-330 \times 10^{6}$ cycles.
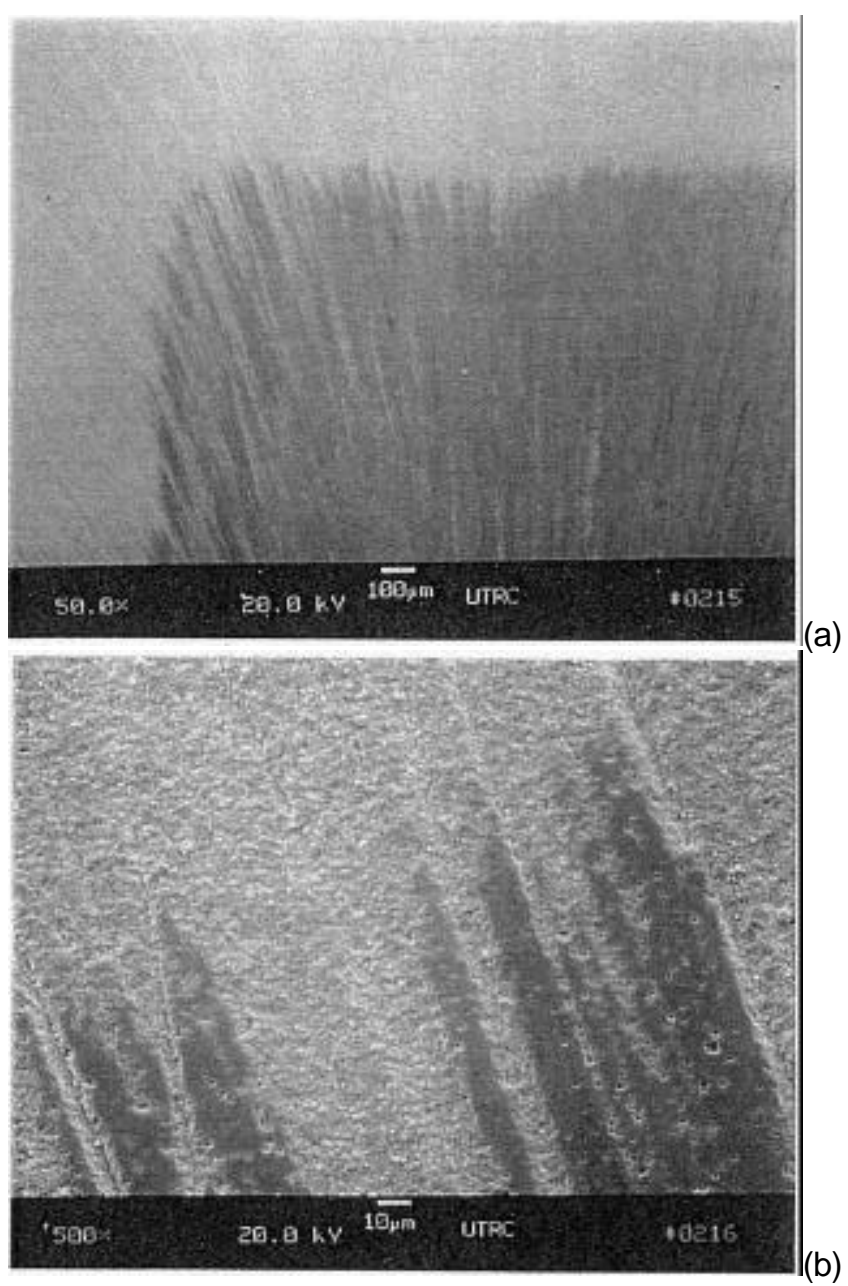

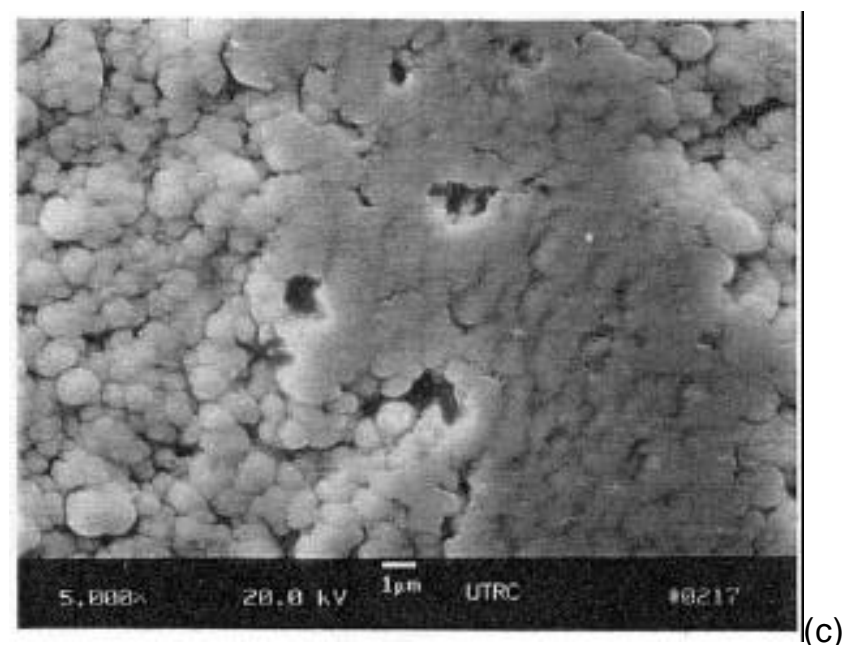

Figure 6 - Scanning electron images of a coated and tested gear. (a) Low resolution image showing the contact pattern (slightly darker area) and grinding patterns. The left portion of the image is the fillet and root region, and the tip of the gear is out of the field-of-view toward the right. (b) Medium resolution image of the region near the low-point of contact on the tooth. (c) High resolution image from an area of figure $6(\mathrm{~b})$ showing the spherical micro-topography of the coating and smoothing of an asperity ridge. 


\section{REFERENCES}

[1] Teeter, F. J., and Berger, M., 1996, "Wear Protection for Gears," Gear Technology, 13(2) pp. 27-29.

[2] Stott, W. R., 1999, "Myths and Miracles of Gear Coatings," Gear Technology, 16(4) pp. 35-44.

[3] Jaochim, F., Kurz, N., and Glatthaar, B., 2002, "Influence of Coatings and Surface Improvements on the Lifetime of Gears", VDI-Berichte NR. 1665, pp. 565-582.

[4] Donnet, C., 1998, "Recent Progress on the Tribology of Doped Diamond-Like and Carbon Alloy Coatings: A Review," Surface and Coatings Technology, 101102, pp. 180-186.

[5] Grill, A., 1997, "Tribology of Diamondlike Carbon and Related Materials: An Updated Review," Surface and Coatings Technology, 94-95, pp. 507-513.

[6] Grill, A., 1998, "Diamond-Like Carbon: State of the Art," Diamond and Related Materials, 8, pp. 428-434.

[7] Naik, S. K., Manesh, A., Mallet, E., and Swiglo, A., 2000, "Surface Reaction Layers and Deposition (Enhanced Surface Protection for Precision Gears)," Presentation for the Advanced Manufacturing Technology for Power Transfer Systems Industry Briefing held at the Illinois Institute of Technology, Chicago, June 13, 2000.

[8] Alanou, M. P., Snidle, R. W., Evans, H. P., and Krantz, T. L., 2002, "On the Performance of Thin Hard Coatings for Gearing Applications," Tribology Transactions, 45(3) pp. 334-344.

[9] Townsend, D. P., and Shimski, J., 1994, "Evaluation of the EHL Film Thickness and Extreme Pressure Additives on Gear Surface Fatigue," NASA TM 106663.

[10] Krantz, T.L., 2002, "The Influence of Roughness on Gear Surface Fatigue", Ph.D. Thesis, Case Western Reserve University, Cleveland, Ohio.

[11] Anderson, N., and Lowenthal, S., 1980, "Spur-GearSystem Efficiency at Part and Full Load," NASA TP1622.

[12] Anderson, N., Lowenthal, S., and Black, J., 1984, "An Analytical Method to Predict Efficiency of Aircraft Gearboxes," NASA TM-83716, AIAA Paper 84-1500.

[13] Hans, M., Buchel, R., Grischke, M., Hobi, R., Zach, M., 2000, "High-volume PVD Coating of Precision Components of Large Volumes at Low Process Costs", Surface and Coatings Technology, 123(2-3) pp. 288-293

[14] Mercer, C., Yao, N., Allameh, S., Evans, A. G., and Cooper, C. V., 2003, Surf. Coat. Technol., in press.

[15] Wang, J. S., Sugimura, Y., Evans, A. G., and Tredway, W. K., 1998, "The mechanical performance of DLC films on steel substrates," Thin Solid Films, 325(1-2) pp. 163-174

[16] Cho, S., Lee, K., Eun, K. Y., Hahn, J. H., and Ko, D., 1999, "Determination Of Elastic Modulus And Poisson's Ratio Of Diamond-Like Carbon Films," Thin Solid Films, 341(1-2) pp. 207-210.
[17] Cooper, C. V., Beetz, Jr., C. P., Buchholtz, B. W., Wilbur, P. J., and Wei, R., 1994, "Spectroscopic And Selected Mechanical-Properties Of Diamond-Like Carbon-Films Synthesized By Broad-Beam lon Deposition From Methane," Diamond And Related Materials, 3(4-6) pp. 534-541.

[18] Cooper, C. V., Holiday, P., and Matthews, A., 1994, "The Effect Of TiN Interlayers On The Indentation Behavior Of Diamond-Like Carbon-Films On Alloy And Compound Substrates", Surface and Coatings Technology, 63(3) pp. 129-134.

[19] Bewilogua, K., Cooper, C. V., Specht, C., Schroder, J., Wittorf, R., and Grischke, M., 2000, "Effect of target material on deposition and properties of metalcontaining DLC (Me-DLC) coatings," Surface and Coatings Technology, 127(2-3) pp. 224-232.

[20] Wang, R., Mercer, C., Evans, A. G., Cooper, C. V., and Yoon, H. K., 2002, "Delamination And Spalling Of Diamond-Like-Carbon Tribological Surfaces," Diamond and Related Materials, 11(10) pp.17971803

[21] Townsend, D. P., Chevalier, J.L., and Zaretsky, E.V., 1973, "Pitting Fatigue Characteristics of AISI M-50 and Super Nitralloy Spur Gears," NASA TN D-7261.

[22] Weibull, W., 1951, "A Statistical Distribution of Wide Applicability," J. Applied Mechanics., 18, pp. 293297.

[23] Hallinan, A. J., 1993, "A Review of the Weibull Distribution," J. of Quality Technology, 25(2), pp. 8593.

[24] Meeker, W. Q., and Escobar, L. A., 1998, Statistical Methods for Reliability Data, John Wiley and Sons, New York, NY.

[25] Krantz, T. L., 2002, "Software for Statistical Analysis of Weibull Distributions With Application to Gear Fatigue Data: User Manual With Verification", NASA TM-2002-211109, ARL-TR-1338.

[26] Jacquelin, J., 1993, "A Reliable Algorithm for the Exact Median Rank Function," IEEE Trans. On Electrical Insulation, 28(2), pp. 168-171.

[27] Johnson, L. G., 1964, The Statistical Treatment of Fatigue Experiments, Elsevier Publishing Co., New York, NY.

[28] Townsend, D.P., 1982, "Effect of Shot Peening on Surface Fatigue Life of Carburized and Hardened AISI 9310 Spur Gears," NASA TP-2047.

[29] Townsend, D.P., Turza, A., and Chaplin, M., 1995, "The Surface Fatigue Life of Contour Induction Hardened AISI 1552 Gears," NASA TM-107017.

[30] Townsend, D.P. and Zaretsky, E.V., 1980, "Comparisons of Modified Vasco X-2 and AISI 9310 Gear Steels," NASA TP-1731.

[31] Townsend, D.P., 1992, "Improvements in Surface Fatigue Life of Hardened Gears by High-Intensity Shot Peening," NASA TM-105678.

[32] Townsend, D.P. and Bamberger, E.N., 1989, "Surface Fatigue Life of Carburized and Hardened M50NiL and AISI 9310 Spur Gears and RollingContact Test Bars," NASA TM-10197. 
[33] Olofsson, U., Sjöström, H., and Sjödin, U., 2000, "Increased Wear Resistance of Roller Bearings Using Me-C: H Coated Rollers", J. of Tribology, $122(4)$ pp. 682-688.

[34] Polonsky, I. A., Chang, T. P., Keer, L. M., and Sproul, W. D., 1998, "A Study of Rolling-Contact Fatigue of Bearing Steel Coated With Physical Vapor Deposition TiN Films: Coating Response to Cyclic Contact Stress and Physical Mechanisms Underlying Coating Effect on the Fatigue Life," Wear, 215, pp. 191-204.

[35] Polonsky, I. A., Chang, T. P., Keer, L. M., and Sproul, W. D., 1997, "An Analysis of the Effect of Hard Coatings on Near-Surface Rolling-Contact Fatigue Initiation Induced by Surface Roughness," Wear, 208, pp. 204-219.

[36] Harris, S. J., and Weiner, A. M., 1998, "Scaling Relationships for the Abrasion of Steel by DiamondLike Carbon Coatings," Wear, 223, pp. 31-36.

[37] Harris, S. J., Weiner, A. M., and Grischke, M., 1999, "Effects of Load on the Abrasion of Steel by MetalContaining Diamond-Like Carbon," Surface and Coatings Technology, 120-121, pp. 561-564.

[38] Borodich, F. M., Harris, S. J., and Keer, L. M., 2002, "Self-Similarity in Abrasion of Metals by Nanosharp Asperities of Hard Carbon Containing Films", Applied Physics Letters, 81(18), pp. 3476-3478.

[39] Harris, S. J., Krauss, G. G., Simko, S. J., Baird, R. J., Gebremariam, S. A., and Doll, G., 2002, "Abrasion and Chemical-Mechanical Polishing Between Steel and a Sputtered Boron Carbide Coating," Wear, 252, pp. 161-169.

[40] Krantz, T., Alanou, M., Evans, H. and Snidle, R.; 2001, "Surface Fatigue Lives of Case-Carburized Gears With an Improved Surface Finish", J. of Tribology, 124(4), pp. 709-716.

[41] Winkelmann, L., Sroka, G., and Swiglo, A., 2001, "The Application of Chemically Accelerated Vibratory Finishing for the Elimination of Wear and Pitting of Alloy Steel Gears", AGMA Paper No. 01FTM07, American Gear Manufacturers Association.

[42] Snidle, R. W., Evans, H. P., and Alanou, M. P., 2002, "Gearing Tribology", Tribological Research and Design for Engineering Systems, Proceedings of the 29th Leeds-Lyon Symposium on Tribology, Elsevier Science. 
Public reporting burden for this collection of information is estimated to average 1 hour per response, including the time for reviewing instructions, searching existing data sources, gathering and maintaining the data needed, and completing and reviewing the collection of information. Send comments regarding this burden estimate or any other aspect of this collection of information, including suggestions for reducing this burden, to Washington Headquarters Services, Directorate for Information Operations and Reports, 1215 Jefferson Davis Highway, Suite 1204, Arlington, VA 22202-4302, and to the Office of Management and Budget, Paperwork Reduction Project (0704-0188), Washington, DC 20503. \begin{tabular}{|l|l|l|}
\hline 1. AGENCY USE ONLY (Leave blank) & $\begin{array}{c}\text { 2. REPORT DATE } \\
\text { August } 2003\end{array}$ & $\begin{array}{r}\text { 3. REPORT TYPE AND DATES COVERED } \\
\text { Technical Memorandum }\end{array}$ \\
\hline
\end{tabular}

4. TITLE AND SUBTITLE 5. FUNDING NUMBERS

Increased Surface Fatigue Lives of Spur Gears by Application of a Coating

6. AUTHOR(S)

WBS-22-708-90-01 1L162211A47A

Timothy L. Krantz, Clark V. Cooper, Dennis P. Townsend, and Bruce D. Hansen 7. PERFORMING ORGANIZATION NAME(S) AND ADDRESS(ES)

National Aeronautics and Space Administration John H. Glenn Research Center at Lewis Field Cleveland, Ohio 44135-3191

8. PERFORMING ORGANIZATION REPORT NUMBER

E-14001

\section{SPONSORING/MONITORING AGENCY NAME(S) AND ADDRESS(ES)}

National Aeronautics and Space Administration

Washington, DC 20546-0001

and

U.S. Army Research Laboratory

Adelphi, Maryland 20783-1145
10. SPONSORING/MONITORING AGENCY REPORT NUMBER

NASA TM-2003-212463

ARL-TR-2971

DETC2003-48114

11. SUPPLEMENTARY NOTES

Prepared for the 2003 International Design Engineering Technical Conferences and Computers and Information in Engineering Conference sponsored by the American Society of Mechanical Engineers, Chicago, Illinois, September 2-6, 2003. Timothy L. Krantz, U.S. Army Research Laboratory, NASA Glenn Research Center; Clark V. Cooper, United Technologies Research Center, East Hartford, Connecticut 06108; Dennis P. Townsend, Townsend Engineering, Westlake, Ohio 44145; and Bruce D. Hansen, Sikorsky Aircraft, Stratford, Connecticut 06601. Responsible person, Timothy L. Krantz, organization code 5950, 216-433-3580.

12a. DISTRIBUTION/AVAILABILITY STATEMENT

Unclassified - Unlimited

Subject Category: 37

Distribution: Nonstandard

Available electronically at http://gltrs.grc.nasa.gov

This publication is available from the NASA Center for AeroSpace Information, 301-621-0390.

13. ABSTRACT (Maximum 200 words)

Hard coatings have potential for increasing gear surface fatigue lives. Experiments were conducted using gears both with and without a metal-containing, carbon-based coating. The gears were case-carburized AISI 9310 steel spur gears. Some gears were provided with the coating by magnetron sputtering. Lives were evaluated by accelerated life tests. For uncoated gears, all of fifteen tests resulted in fatigue failure before completing 275 million revolutions. For coated gears, eleven of the fourteen tests were suspended with no fatigue failure after 275 million revolutions. The improved life owing to the coating, approximately a six-fold increase, was a statistically significant result.

14. SUBJECT TERMS

15. NUMBER OF PAGES

Gears; Fatigue life; Accelerated life tests; Pitting; Coatings

15

17. SECURITY CLASSIFICATION OF REPORT

Unclassified
18. SECURITY CLASSIFICATION OF THIS PAGE

Unclassified
19. SECURITY CLASSIFICATION OF ABSTRACT

Unclassified
16. PRICE CODE

20. LIMITATION OF ABSTRACT

Standard Form 298 (Rev. 2-89)

Prescribed by ANSI Std. Z39-18 298-102 

